\title{
PENGARUH PEMBERIAN AMPAS TAHU FERMENTASI SEBAGAI PAKAN KONVENSIONAL TERHADAP BIAYA PRODUKSI ITIK PEDAGING
}

\section{THE EFFECT OF FERMENTED TOFU WASTE AS CONVENTIONAL FEED ON THE COST OF DUCK PRODUCTION}

\author{
Agus Hadi Prayitno, Budi Prasetyo, Anang Sutirtoadi, dan Ahmad Sa'Roni \\ Jurusan Peternakan, Politeknik Negeri Jember \\ Email: agushp@polije.ac.id
}

\begin{abstract}
INTISARI
Penelitian ini dilakukan untuk mengetahui pengaruh pemberian ampas tahu fermentasi (ATF) sebagai pakan konvensional terhadap biaya produksi itik pedaging. Sebanyak 200 ekor day old duck (DOD). Rancangan percobaan yang digunakan adalah rancangan acak lengkap (RAL) yang terdiri dari 4 perlakuan pakan. Setiap perlakuan masing-masing terdiri dari 5 kali ulangan. Masing-masing ulangan terdiri dari 10 ekor DOD. Perlakuan penelitian yaitu: P0 (100\% BR1), P1 (90\% BR1 dan 10\% ATF), P2 (80\% BR1 dan 20\% ATF), dan P3 (70\% BR1 dan 30\% ATF). Parameter yang diuji yaitu biaya produksi, pendapatan, dan income over feed cost. Data hasil penelitian dianalisis menggunakan analisis ragam (ANOVA). Hasil yang berbeda dilanjutkan dengan uji Beda Nyata Terkecil (BNT 1\% dan 5\%). Pemberian ATF sampai level 30\% dalam pakan berpengaruh $(\mathrm{P}<0,05)$ terhadap biaya pakan dan sangat berpengaruh $(\mathrm{P}<0,01)$ terhadap income over feed cost, namun tidak berpengaruh terhadap pendapatan. Pemberian ATF dalam pakan sampai level $30 \%$ sebagai pakan konvensional dapat menurunkan biaya produksi dalam pemeliharaan itik pedaging.
\end{abstract}

Kata kunci: Ampas Tahu Fermentasi, Pakan Konvensional, Biaya Produksi, Itik Pedaging

\begin{abstract}
This study was conducted to determine the effect of fermented tofu waste (ATF) as conventional feed on the cost of broiler duck production. 200 day old ducks (DOD) were maintained. The experimental design used a completely randomized design (CRD) consisting of 4 feed treatments. Each treatment consisted of 5 replications. Each replication consisted of 10 DOD. The research treatments were: P0 (100\% BR1), P1 (90\% BR1 and 10\% ATF), P2 (80\% BR1 and 20\% ATF), and P3 (70\% BR1 and 30\% ATF). The parameters were production costs, income, and income over feed costs. The results were analyzed using analysis of variance (ANOVA). Different results continued using the Least Significant Difference test (LSD 1\% and 5\%). Giving ATF to level 30\% in feed had an effect $(P<0.05)$ on feed costs and was highly significant $(P<0.01)$ on income over feed costs, but does not affect income. Giving ATF in feed up to level 30\% as conventional feed can reduce production costs in maintaining of ducks.
\end{abstract}

Keywords: Fermented Tofu Waste, Conventional Feed, Production Costs, Ducks

\section{PENDAHULUAN}

Usaha pemeliharaan itik kini semakin berkembang. Itik merupakan jenis unggas yang memiliki potensi dwiguna yaitu sebagai penghasil telur dan daging. Itik sebagai salah satu alternatif yang mendukung pemenuhan kebutuhan masyarakat akan protein hewani. Itik memiliki kemampuan lebih tahan penyakit, dapat dipelihara tanpa atau dengan air serta pertumbuhannya lebih cepat dari ayam buras. Itik mempunyai kelebihan dibanding ternak ayam karena mampu mengkonsumsi bahan-bahan dengan kadar 
serat kasar (SK) tinggi yaitu sampai 30\%(Maghfiroh et al., 2012).

Pengembangan usaha peternakan itik pedaging di Indonesia saat ini masih mengalami berbagai kendala. Salah satu dari kendala dalam pengembangan usaha peternakan itik yaitu penyediaan pakan yang berkualitas. Kendala dalam penyediaan pakan meliputi ketersediaan bahan baku pakan yang berkualitas. Harga dari bahan pakan sumber protein relatif mahal seperti tepung ikan dan bungkil kedelai yang masih impor. Biaya pakan pada usaha peternakan mencapai 60 sampai $75 \%$ dari total biaya produksi (Sibbald, 1987). Biaya pakan dapat ditekan dengan cara mencari sumber bahan baku yang lebih murah, mudah didapat, berkualitas, tetapi tidak bersaing dengan kebutuhan manusia. Oleh karena itu, perlu digali potensi bahan pakan lokal yang banyak tersedia. Apabila biaya pakan dapat ditekan, maka akan meningkatkan keuntungan peternak dan sekaligus membantu mengembangkan usaha pemeliharaan itik pedaging.

Pemberian pakan konvensional dilakukan untuk mengantisipasi mahalnya harga pakan pola usaha tani ternak khususnya itik pedaging. Pakan berperan sangat penting dalam usaha peternakan itik. Bahan pakan yang digunakan untuk kebutuhan pakan itik di lokasi penelitian diperoleh petani dengan cara membeli. Biaya pemeliharaan itik sebagian besar berasal dari pakan yaitu sebesar lebih besar dari 70\% (Ketaren, 2002). Jenis itik yang diintroduksi adalah itik peking mojosari putih (PMP) dan pakan yang diberikan adalah pakan organik. Kegiatan ini dilakukan agar anggota kelompok bisa meminimalkan biaya pakan yang mahal dan sangat fluktuatif. Permasalahan pada usaha itik PMP dengan pakan organik yang dikandangkan belum diketahui apakah usaha tersebut menguntungkan atau tidak. Kelompok tani juga belum memperhitungkan besarnya biaya variabel seperti biaya pakan, tenaga kerja, dan obat-obatan (Lembong et al., 2015)

Biaya pakan merupakan komponen dari pengeluaran usaha produksi dalam kegiatan pemeliharaan itik yang terbesar, sehingga ternak harus diberi pakan dengan jumlah dan kualitas yang sesuai kebutuhannya. Oleh karena itu, upaya menekan biaya pakan diharapkan dapat meningkatkan keuntungan bagi peternak dan dapat membantu dalam pengembangan usaha pemeliharaan itik penghasil daging dan telur. Salah satu caranya adalah dengan memanfaatkan bahan baku lokal seperti ampas tahu. Industri tahu di Indonesia diketahui berkembang dengan cepat. Jumlah industri tahu di Indonesia mencapai kurang lebih 84.000 unit usaha dengan kapasitas produksi lebih dari 2.560.000 ton per tahun (Setiawan dan Rusdjijati, 2014).

Limbah industri tahu pada umumnya dibagi menjadi dua bentuk limbah, yaitu limbah padat dan limbah cair. Limbah padat pabrik pengolahan tahu berupa kotoran hasil pembersihan kedelai (batu, tanah, kulit kedelai, dan benda padat lain yang menempel pada kedelai) dan sisa saringan bubur kedelai yang disebut dengan ampas tahu (Setiawan dan Rusdjijati, 2014). Ampas tahu dapat dijadikan sebagai bahan pakan tambahan untuk meningkatkan performa itik yaitu pada bobot daging yang dihasilkan, karena berdasarkan komposisi kimianya ampas tahu dapat digunakan sebagai sumber protein. Kandungan protein dan lemak pada ampas tahu cukup tinggi yang tergantung tempat dan cara pemrosesannya. Komposisi ampas tahu yaitu $8,66 \%$ protein, 3,79\% lemak, 51,63\% air, dan 1,21\% abu (Dinas Peternakan Provinsi Jawa Timur, 2011).

Pemanfaatan ampas tahu sebagai pakan tambah pada pemeliharaan itik selain dapat menekan biaya pemeliharaan diharapkan dapat meningkatkan bobot itik. Pemnfaatan ampas tahu sebagai pakan itik juga membantu mengurangi masalah pencemaran lingkungan dari limbah industri tahu. Penelitian ini bertujuan untuk mengetahui seberapa besar pengaruh ampas tahu dalam meningkatkan bobot pertumbuhan itik sehingga berdampak pada efisiensi biaya pakan, pendapatan, dan income over feed cost (IOFC).

\section{MATERI DAN METODE}

Penelitian ini dilaksanakan di kandang itik Desa Suco, Kecamatan Mumbulsari, Kabupaten Jember. Bahan pakan yang digunakan pada penelitian ini dilakukan analisis kandungan protein kasar (PK), lemak kasar (LK), dan serat kasar (SK) pada ampas tahu fermentasi (ATF) diuji di Laboratorium Teknologi Pakan, Jurusan Peternakan, Politeknik Negeri Jember. 


\section{Materi Penelitian}

Materi yang digunakan dalam penelitian yaitu 200 ekor day old duck (DOD), pakan komersil (BR1), ampas tahu, dan ragi tape yang digunakan untuk proses fermentasi. Kandang yang digunakan adalah kandang litter yang disekat dengan bambu sesuai dengan perlakuan yang diberikan.

\section{Metode Penelitian}

\section{Proses pembuatan ampas tahu fermentasi}

Ampas tahu (basah) diperas sampai airnya keluar. Ampas tahu dikeringkan dengan cara dijemur sekitar 2 sampai 3 hari. Air sebanyak 7 sampai 8 liter dicampur dengan ragi tape sebanyak 5 g. Setiap $10 \mathrm{~kg}$ ampas tahu yang sudah kering dicampur dengan air campuran ragi tape sebanyak 7 sampai 8 liter dan diaduk sampai rata. Ampas tahu yang telah dicampur dengan air campuran ragi tape disimpan dalam kondisi tertutup selama 2 sampai 3 hari. Ampas tahu fermentasi yang sudah jadi digunakan dalam penelitian ini. Kandungan nutrisi dan harga pakan perlakuan disajikan pada Tabel 1 .

\section{Pemeliharaan itik}

Penelitian ini dilakukan mulai dari tahap persiapan pemeliharaan yaitu kegiatan sanitasi kandang dan pembersihan peralatan, kemudian dilakukan persiapan plot-plot kandang dengan luas lantai tiap plot perlakuan. Persiapan sebelum day old duck (DOD) datang meliputi persiapan pemanas dan alas kandang serta air gula 4 sampai 5 jam sebelum kedatangan DOD.

Setiap plot kandang disediakan lampu pijar sebagai pemanas dan dilengkapi dengan lampu penerangan. Lama pemeliharaan dalam penelitian ini dilakukan selama 42 hari. Tahap pelaksanaan penelitian meliputi kegiatan pemberian pakan dan minum secara ad libitum. Kegiatan vaksinasi ND-IB dilakukan pada umur 4 hari. Pada umur 14 hari dilakukan vaksin gumboro dan pengulangan vaksinasi ND-IB. Konsumsi pakan dicatat setiap hari. Pertambahan bobot badan dan konversi pakan dilakukan pengukuran setiap minggu.

\section{Parameter}

Biaya produksi. Biaya produksi dalam pemeliharaan ini adalah jumlah konsumsi pakan (kg) dikalikan dengan harga pakan.
Biaya produksi $=$ Konsumsi pakan $(\mathrm{Kg}) \mathrm{x}$ Harga pakan (Rp)

Pendapatan. Pendapatan merupakan besarnya uang yang dihasilkan dari aktivitas produksi. Pendapatan dihitung dari total produk itik yang dihasilkan (kg) dikalikan dengan harga jual itik seperti yang disajikan pada Tabel 4.

Pendapatan $=$ Total produksi $(\mathrm{kg}) \times$ Harga jual (Rp)

Income over feed cost. Income over feed cost merupakan selisih antara pendapatan terhadap biaya pakan yang dikeluarkan. IOFC diukur untuk dapat mengetahui seberapa besarnya biaya pakan yang dikeluarkan. IOFC diukur dengan cara mencari selisih antara pendapatan yang diterima (Rp) dengan biaya pakan yang dikonsumsi itik selama pemeliharaan (Rp).

Income over feed cost $=$ Pendapatan $(\mathrm{Rp})-$ Biaya produksi (Rp)

\section{Analisis data}

Penelitian ini dilakukan menggunakan metode eksperimental menurut Fuchan (2004). Rancangan percobaan yang digunakan adalah rancangan acak lengkap (RAL) yang terdiri dari 4 perlakuan pakan. Setiap perlakuan masing-masing terdiri dari 5 kali ulangan. Masing-masing ulangan terdiri dari 10 ekor DOD. Model matematika rancangan acak lengkap (RAL) yang digunakan menurut Hanafiah (2003) adalah sebagai berikut:

Keterangan:

$$
\mathrm{Y}_{\mathrm{ij}}=\mu+\tau_{\mathrm{i}}+\varepsilon_{\mathrm{ij}}
$$

$\mathrm{Y}_{\mathrm{ij}}=$ hasil pengamatan dari perlakuan tingkat

ke-i dan pada ulangan ke-j

$\mathrm{i}=$ perlakuan

$\mathrm{j}=$ ulangan

$\mu=$ rataan umum (mean)

$\tau_{\mathrm{i}}=$ pengaruh perlakun ke-i

$\varepsilon_{\mathrm{ij}}=$ pengaruh galat (experimental error) perlakuan ke-i dan ulangan ke-j

Data dari hasil penelitian ini dianalisis menggunakan analisis ragam (ANOVA). Hasil yang berbeda dilanjutkan dengan uji Beda Nyata Terkecil (BNT 1\% dan 5\%). 
Tabel 1. Kandungan Nutrisi dan Harga Pakan Perlakuan

\begin{tabular}{|c|c|c|c|c|}
\hline Pakan & P1 (\%) & P2 (\%) & P3 (\%) & P4 (\%) \\
\hline BR1 & 100 & 90 & 80 & 70 \\
\hline ATF & 0 & 10 & 20 & 30 \\
\hline PK (\%) & 21 & 20,97 & 20,94 & 20,91 \\
\hline EM (kkal) & 3.000 & 2.990 & 2.980 & 2.970 \\
\hline $\mathrm{Rp} / \mathrm{kg}$ & 6.800 & 6.320 & 5.840 & 5.360 \\
\hline
\end{tabular}

Keterangan:

P0 = Pakan itik BR1 (100\%) : ATF (0\%)

P1 = Pakan itik BR1 $(90 \%):$ ATF $(10 \%$

P2 = Pakan itik BR1 $(80 \%):$ ATF $(20 \%)$

P3 = Pakan itik BR1 (70\%): ATF (30\%)

\section{HASIL DAN PEMBAHASAN}

Penelitian ini dilakukan dalam upaya menggunakan ampas tahu sebagai campuran pakan itik dengan cara fermentasi untuk memperbaiki kualitas ampas tahu. Hasil penelitian menunjukkan nilai rerata konsumsi pakan, biaya produksi, pendapatan, dan IOFC seperti yang tersaji pada Tabel 2.

\section{Biaya Produksi}

Hasil analisis menunjukkan bahwa ATF mempunyai potensi yang baik sebagai bahan pakan itik. Harga ATF setelah dikeringkan Rp2000,00/kg dan ini menunjukkan bahwa ATF sebagai bahan pakan berpotensi untuk dapat menurunkan biaya pakan itik, karena apabila hanya menggunakan pakan komersil BR1 dengan harga pada saat dilakukan penelitian yaitu Rp6.800,00/kg akan dapat membebani biaya produksi pemeliharaan itik. Kandungan nutrisi dari hasil analisis ampas tahu fermentasi disajikan pada Tabel 2.

Rasyaf (2006) menyatakan bahwa tinggi rendahnya harga suatu unsur nutrisi tergantung pada fungsi unsur nutrisi itu untuk proses hidup dan produksi. Semakin besar peran suatu unsur nutrisi, akan semakin tinggi harganya. Unsur nutrisi yang memenuhi hal tersebut adalah protein dan energi serta kebutuhan nutrisi unggas harus terpenuhi melalui ransum yang disusun.

Tabel 2. Rerata Konsumsi Pakan, Biaya Produksi, Pendapatan, dan Income Over Feed Cost

\begin{tabular}{ccccc}
\hline Perlakuan & $\begin{array}{c}\text { Konsumsi Pakan } \\
\text { (g/ekor) }\end{array}$ & $\begin{array}{c}\text { Biaya Pakan } \\
\text { (Rp) }\end{array}$ & $\begin{array}{c}\text { Pendapatan } \\
\text { (Rp/ekor) }\end{array}$ & $\begin{array}{c}\text { IOFC } \\
\text { (Rp/ekor) }\end{array}$ \\
\hline P0 & $3.655,5$ & $2.3760,6^{\mathrm{a}}$ & $19913,2^{\text {ns }}$ & $-4.094,0^{\mathrm{c}}$ \\
P1 & $3.541,8$ & $2.1428,1^{\mathrm{a}, \mathrm{b}}$ & $20389,2^{\text {ns }}$ & $-873,1^{\mathrm{c}, \mathrm{d}}$ \\
P2 & $3.337,5$ & $1.8690,0^{\mathrm{b}}$ & $20195,6^{\text {ns }}$ & $1.642,9^{\mathrm{d}}$ \\
P3 & $3.505,5$ & $1.8053,3^{\mathrm{b}}$ & $19385,5^{\text {ns }}$ & $1.499,1^{\mathrm{d}}$ \\
\hline
\end{tabular}

ns Tidak berbeda nyata

a,b Superskrip yang berbeda pada kolom yang sama menunjukkan perbedaan yang nyata $(\mathrm{P}<0,05)$

$c, d$ Superskrip yang berbeda pada kolom yang sama menunjukkan perbedaan yang sangat nyata $(\mathrm{P}<0,01)$

Itik pedaging merupakan salah jenis unggas yang cukup populer pada saat ini. Peternak telah banyak mengusahakan sebagai sumber penghasil daging unggas. Namun, pada saat ini belum tersedia secara khusus pakan untuk itik pedaging. Kondisi ini menyebabkan biaya pakan itik menjadi sangat tinggi dan tidak sesuai dengan produktivitas itik pedaging yang masih di bawah ayam pedaging. Wakhid (2010) menyatakan bahwa pemeliharaan itik secara intensif di Indonesia memiliki pola pemberian pakan terkontrol yaitu dengan memberikan pakan komersial yang kandungan nutrisinya sudah disusun menggunakan formulasi yang akurat.

Harga pakan berdasarkan perlakuan (Tabel 1) secara berturut-turut, yaitu: Rp6.800,00/kg (P0), Rp6.320,00/kg (P1), Rp5.840,00/kg (P2), dan Rp5.360,00 (P3). Kandungan protein kasar (PK) pada pakan perlakuan yaitu sekitar 20 sampai $21 \%$, hal ini dengan mempertimbangkan kebutuhan PK itik pedaging untuk dapat menunjang produksi yang cukup tinggi. Kebutuhan protein itik pedaging pada periode starter yaitu sekitar $22 \%$ dan energi metabolisme 
(EM) $2.900 \mathrm{kkal} / \mathrm{kg}$, sedangkan pada periode finisher protein yang dibutuhkan sekitar 16\% dan EM sekitar $3.000 \mathrm{kkal} / \mathrm{kg}$ (NRC, 1994). Kebutuhan protein pada itik pedaging lebih rendah jika dibandingkan dengan kebutuhan protein ayam broiler, hal ini berkaitan dengan lama waktu yang diperlukan untuk mencapai pertumbuhan yang optimal.

Tabel 3. Kandungan Nutrisi Ampas Tahu Sebelum dan Sesudah Difermentasi

\begin{tabular}{clcccc}
\hline No. & Bahan Pakan & PK (\%) & LK (\%) & SK (\%) & Abu (\%) \\
\hline 1 & Ampas tahu (basah) & 2,91 & 1,39 & 3,76 & 0,58 \\
2 & Ampas tahu fermentasi & 20,7 & 6,5 & 18,6 & 3,6 \\
\hline
\end{tabular}

Pemberian ATF sampai level $30 \%$ berpengaruh nyata $(\mathrm{P}<0,05)$ terhadap biaya pakan itik pedaging. Pemberian ATF dalam pakan itik dapat menurunkan harga pakan (Tabel 1) dan setelah dilakukan pemeliharaan selama 42 hari, tingkat konsumsi juga menunjukkan selisih jumlah yang berbeda diantara perlakuan. Hal ini menunjukkan bahwa pemberian ATF untuk menggantikan BR1 sampai level 30\% dalam pakan tetap terjaga tingkat konsumsinya. Konsumsi yang dihasilkan menunjukkan bahwa ATF tidak mempengaruhi tingkat palatabilitas pakan.

Rerata konsumsi pakan pada perlakuan P2 dan P3 menunjukkan jumlah konsumsi pakan terendah. Hal ini menunjukkan bahwa pemberian ATF dalam pakan itik pedaging meningkatkan efisiensi dalam pemeliharaan. Semakin tinggi level pemberian ATF dalam pakan itik pedaging semakin menurun biaya pakan. Biaya pakan merupakan komponen biaya terbesar dalam kegiatan pemeliharaan itik. Itik harus diberi pakan dengan jumlah dan kualitas yang sesuai dengan kebutuhannya untuk pertumbuhannya. Hal ini akan berdampak pada biaya pakan yang lebih tinggi. Oleh karena itu, upaya menekan biaya pakan salah satunya dengan penggunaan bahan baku lokal yaitu dengan memanfaatkan ampas tahu. Industri tahu di Indonesia diketahui berkembang dengan cepat, menurut Setiawan dan Rusdjijati (2014) terdapat 84.000 unit industri tahu di Indonesia dengan kapasitas produksi mencapai 2.560 .000 ton per tahun.

Pencapaian tingkat konsumsi pakan yang diimbangi dengan efisiensi biaya diharapkan akan menjadi faktor yang menentukan keberhasilan peternak dalam mencapai produksi yang optimal namun juga diimbangi keuntungan yang sesuai dengan harapan. Misnadi (2009) menyatakan bahwa pemberian ampas tahu dengan batasan tertentu memberikan dampak yang positif terhadap unggas. Kandungan protein dalam bahan pakan sering dijadikan sebagai indikator penentu kualitas pakan (Supriyadi, 2009).

\section{Pendapatan}

Itik hibrida merupakan itik hasil persilangan yang diharapkan dapat memberikan produktivitas yang lebih baik dalam menghasilkan daging. Oleh karena itu, itik hibrida pada saat ini banyak diusahakan oleh peternak. Sebagai penghasil daging, penjualan itik berbeda dengan ayam pedaging. Itik pedaging akan dibeli oleh pedagang berdasarkan kategori bobot hidup yang akan terbagi menjadi beberapa ukuran. Menurut Rasyaf (2006), besarnya pendapatan dari usaha ternak itik merupakan salah satu pengukur yang penting untuk mengetahui seberapa jauh usaha peternakan itik mencapai keberhasilan.

Kategori bobot dan harga jual itik disajikan pada Tabel 4 dan rerata persentase bobot itik pedaging umur 42 hari disajikan pada Tabel 5. Hasil dari analisis ragam menunjukkan bahwa pemberian ATF tidak berbeda $(\mathrm{P}>0,05)$ terhadap pendapatan. Hal ini dapat terjadi karena secara keseluruhan bobot panen masing-masing plot percobaan perlakuan memberikan hasil yang sama. Artinya, baik pemeliharaan itik pada perlakuan P0, P1, P2, dan P3 memberikan tingkat pertumbuhan yang sama. Tabel 5 menunjukkan variasi yang cukup besar pada hasil panen itik, sebagian besar masih masuk pada kategori sedang dan kecil yaitu mencapai proporsi 21 sampai $32 \%$ atau total ukuran sedang dan kecil mencapai sekitar 50\% pada masing-masing perlakuan. Kondisi ini menunjukkan bahwa keragaman bibit itik pedaging hibrida yang cukup besar. Itik dipanen pada umur 42 hari dengan harapan mendapatkan itik dengan bobot hidup yang cukup besar. 
Tabel 4. Kategori Bobot dan Harga Jual Itik

\begin{tabular}{cccc}
\hline No. & Bobot Hidup $(\mathrm{g})$ & Harga (Rp/ekor) & Kategori \\
\hline 1 & $\leq 700-949$ & 13.000 & Kecil \\
2 & $\geq 950-1.099$ & 18.000 & Sedang \\
3 & $\geq 1.100-1.199$ & 24.000 & Standar \\
4 & $\geq 1.200-1.400$ & 26.000 & Besar \\
\hline
\end{tabular}

Pemberian ATF berpotensi sebagai bahan pakan alternatif yang lebih efisien dalam pemeliharaan itik pedaging. Pemberian ATF sampai level $30 \%$ dalam pakan menunjukkan semakin menurunkan biaya pakan yang dibutuhkan selama pemeliharaan, meskipun dari hasil pendapatan tidak berbeda. Hal ini disebabkan oleh harga jual itik yang didasarkan pada kategori bobot hidup sehingga akumulasi total pendapatan tidak berbeda. Empat kategori ukuran itik pedaging, yaitu: besar, standar, sedang, dan kecil. Rasyid (2013) menyatakan bahwa penambahan ampas tahu dapat meningkatkan efisiensi penggunaan ransum ayam kampung, karena konsumsi pakan yang tinggi diikuti oleh pembentukan daging sehingga berpengaruh terhadap pertambahan bobot badan. Hasil penjualan yang diharapkan adalah sebagian besar itik dapat mencapai ukuran terbesar artinya itik mempunyai berat hidup pada kategori harga tertinggi.

Tabel 5. Rerata Persentase Bobot Itik Pedaging Umur 42 Hari

\begin{tabular}{ccccc}
\hline \multirow{2}{*}{ Perlakuan } & \multicolumn{4}{c}{ Ukuran Panen } \\
\cline { 2 - 5 } & Besar & Standar & Sedang & Kecil \\
\hline P0 & $12 \%$ & $31 \%$ & $32 \%$ & $24 \%$ \\
P1 & $13 \%$ & $43 \%$ & $24 \%$ & $21 \%$ \\
P2 & $34 \%$ & $16 \%$ & $24 \%$ & $26 \%$ \\
P3 & $18 \%$ & $29 \%$ & $21 \%$ & $32 \%$ \\
\hline
\end{tabular}

\section{Income Over Feed Cost}

Besarnya biaya pakan menjadi faktor penting yang harus diperhatikan dalam usaha peternakan. Pemilihan bahan pakan yang tepat tidak hanya pada kualitas yang baik tetapi juga harus diimbangi dengan harga yang bersaing, sehingga nilai ekonomis akan dapat tercapai. Berikut ini adalah hasil perhitungan IOFC pemeliharaan itik pedaging seperti yang disajikan pada Tabel 2. Hasil sidik ragam menunjukkan bahwa pemberian ATF dalam pakan itik berpengaruh sangat nyata $(\mathrm{P}<0,01)$ terhadap nilai IOFC. Pendapatan pemeliharaan pada P0, P1, P2, dan P3 menunjukkan hasil yang tidak berbeda meskipun demikian pada P1 memberikan pendapatan yang negatif. Hal ini menunjukkan bahwa penggunaan ATF memberikan kesempatan pendapatan yang lebih baik pada pemeliharaan itik pedaging hibrida.

Biaya pakan pada pemeliharaan itik yang dikeluarkan seharusnya berbanding lurus dengan tingkat produksi yang dihasilkan. Hal tersebut dapat tercapai apabila pakan yang digunakan mempunyai kualitas yang sesuai dengan kebutuhan ternak untuk berproduksi lebih baik. Selain aspek kualitas, sisi harga juga menjadi pertimbangan agar ternak dapat berproduksi tinggi namun dengan biaya yang murah. Hasil penelitian Subagja et al. (2017) menunjukkan bahwa secara parsial bibit atau DOD, pakan, harga obat, harga vitamin, bahan bakar, dan tenaga kerja berpengaruh terhadap keuntungan usaha ternak itik pedaging. Tabel 1 menunjukkan bahwa penggunaaan ATF dapat menurunkan harga pakan, karena dengan tingkat produksi yang tidak berbeda. Perlakuan ATF yang semakin besar juga menghasilkan pendapatan yang semakin tinggi.

Konsep penyediaan bahan pakan itik pedaging memiliki peranan yang penting, dimana tidak hanya kualitas pakan dalam hal ini kandungan nutrisi, namun juga perlu memperhatikan harga pakan untuk meningkatkan efisiensi pemeliharaan. Itik pedaging hibrida yang digunakan dalam penelitian adalah hasil persilangan Itik Peking dan Itik Khaki Chambell yang bertujuan untuk meningkatkan produksi itik khususnya kecepatan produksi daging. Oleh karena itu, 
banyak digunakan pakan broiler dalam pemeliharaannya, tapi seperti pada penelitian ini pencapaian bobot badan tertinggi pada umur 42 hari adalah $1,4 \mathrm{~kg}$ dan tidak mencapai 50\% dari jumlah pemeliharaan. Hal ini menunjukkan bahwa itik hibrida secara genetik tidak efisien bila hanya diberikan pakan dengan kualitas PK 21\%. Hasil penelitian menunjukkan bahwa penggunaan ampas tahu fermentasi, secara kualitas dan harga memberikan tingkat pembiayaan pakan yang lebih murah dan tetap memberikan produksi yang cukup baik. Penggunaan pada skala usaha akan dapat membantu peternak dalam efisiensi biaya pakan, karena dengan biaya dan produksi yang dihasilkan dapat mengurangi risiko kerugian dan memberikan keuntungan yang lebih baik.

\section{KESIMPULAN DAN SARAN}

\section{Kesimpulan}

Pemberian ATF dalam pakan sampai level 30\% sebagai pakan konvensional dapat menekan biaya produksi dalam pemeliharaan itik pedaging.

\section{Saran}

Ampas tahu fermentasi sebagai pakan konvensional disarankan sampai level 30\% yang diberikan dalam pakan itik pedaging agar dapat memberikan pengaruh terhadap efisiensi biaya produksi selama pemeliharaan.

\section{DAFTAR PUSTAKA}

Dinas Peternakan Provinsi Jawa Timur. 2011. Pemanfaatan Ampas Tahu Sebagai Pakan Unggas. http://disnak.jatimprov.go.id/web/laya nanpublik/readtehnologi/811/pemanfa atan--as-tahu-sebagai-pakan-unggas.

Diakses tanggal 14 Juli 2017.

Furchan, A. 2004. Pengantar Penelitian Dalam Pendidikan. Pustaka Pelajar. Yogyakarta.

Hanafiah, K.A. 2003. Rancangan Percobaan Teori dan Aplikasi. PT Raja Grafindo Persada. Jakarta.

Ketaren, P.P. 2002. Kebutuhan gizi itik petelur dan itik pedaging. Wartazoa. 12(2):3746.

Lembong, J.E., N.M. Santa, A. Makalew, dan F.H. Elly. 2015. Analisis break even point usaha ternak itik pedaging (studi kasus pada usaha itik milik kelompok masawang di desa talikuran kecamatan remboken). Jurnal Zootek. 35 (1):39-45.

Maghfiroh, K., I. Mangisah dan V.D.Y.B. Ismadi. 2012. Pengaruh penambahan sari jeruk nipis (Citrus aurantifolia) dalam ransum terhadap kecernaan protein kasar dan retensi nitrogen pada itik magelang jantan. Animal Agriculture Journal. 1(1):669-683.

Misnadi. 2009. Pemanfaatan Ampas Tahu pada Unggas. https://fdokumen.com/document/pem anfaatan-ampas-tahu-padaunggasdoc.html. Diakses tanggal $14 \mathrm{Juli}$ 2017.

National Research Council (NRC). 1994. Nutrient Requirement of Poultry, 9th Revised Edition. National Academy Press. Washington DC.

Rasyaf, M. 2006. Beternak Itik Komersial. Cetakan ke-21. Penerbit Kanisius. Yogyakarta.

Rasyid, S. 2013. Evaluasi pertambahan bobot badan dan efisiensi penggunaan pakan pada itik pedaging yang diberi level ampas tahu yang berbeda. Jurnal Galung Tropika. 1:9-13.

Setiawan, A. dan R. Rusdjijati. 2014. Peningkatan kualitas biogas limbah cair tahu dengan metode taguchi. Prosiding SNATIF Ke-1. Fakultas Teknik, Universitas Muria Kudus. Hal. 35-40.

Sibbald, I.R. 1987. Estimation of bio available amino acids in feeding stuffs for poultry and pigs: a review with emphasis on balance experiment. The Canadian Veterinary Journal. 67(2):221-301.

Subagja, H., B. Prasetyo, dan H. Nurjanah. 2017. Faktor produksi usaha ternak itik petelur semi intensif di Kabupaten Jember. Jurnal Ilmiah Inovasi. 17(2):6772.

Supriyadi. 2009. Panduan Lengkap Itik. Cetakan ke-1. Penebar Swadaya. Jakarta Wakhid, A. 2010. Buku Pintar Beternak dan Bisnis Itik. Cetakan ke-1. Agromedia Pustaka. Jakarta. 